\title{
АКТУАЛЬНЫЕ ПРОБЛЕМЫ ФИНАНСО-ПРАВОВОЙ МОДЕРНИЗАЦИИ «МУСОРНОЙ РЕФОРМЫ»
}

\section{CURRENT PROBLEMS OF FINANCIAL AND LEGAL MODERNIZATION OF THE "GARBAGE REFORM»}

A. Lobko

Summary. Based on a thorough analysis of information from reliable public sources the conclusion that "trash reform", in the form in which the government actively imposes now the citizens of the country, is sustainable modernization breakthrough or a breakthrough in the field of processing and utilization of solid domestic waste (SDW) is not remedied leads to loss of time, causes billions of dollars damage to the economy and society. Suggested by the authors' imagination as an ideal model for waste disposal, in fact, it turned out to be unattainable for objective reasons. The gap between the ideal expected and the real proved to be untenable with a stagnant economy, high levels of corruption, inefficient management, and many unresolved socio-economic problems. The creators of the" garbage reform " propose to compensate the impoverished population and dilapidated businesses that have been robbed by excessive taxes. Necessary changes in regulations changes to "trash reform", based on the findings in this article fundamental flaws that drove the common sense of the previous plans, turned most of the original people ideas "junk change" in the not executed and will not be able to provide any real fundamental improvement of ecology in Russia.

Keyword. "Garbage reform", New municipal service" handling of MSW", Public law company (PPC) Russian environmental operator (REO), limited liability Companies (LLC) regional operators, Public joint stock companies for handling MSW, garbage protests.

\author{
Лобко Анастасия Александровна \\ Московский государственный университет \\ им. М. В. Ломоносова \\ naty.rubik@mail.ru
}

Аннотация. На основе тщательного анализа информации из достоверных открытых источников делается вывод, что «мусорная реформа», в том виде, в котором правительство РФ активно её навязывает сейчас гражданам страны, вместо устойчивой модернизации, прорыва или рывка в отрасли по переработке и утилизации твердо-бытовых отходов (ТБ0) ведёт к не поправимой потере времени, наносит многомиллиардный ущерб экономике и обществу. Предложенная по воображению авторов, как идеальная модель утилизации мусора на деле оказалась недостижимой по объективным причинам. Разрыв между идеальным ожидаемым и реальным оказался неподъёмным при стагнирующей экономике, высоком уровне коррупции, неэффективном менеджменте и множеством нерешённых социально-экономических проблем. Нанесённый вред создатели «мусорной реформы» предлагают вновь возмещать обобранному непомерными налогами обнищавшему населению и полуразорённому бизнесу. Необходимо изменение законодательных норм по существенной корректировке «мусорной реформы», исходя из выявленных в данной статье принципиальных недостатков, которые вытеснили здравый смысл из прежних замыслов, превратили большинство первоначально востребованных гражданами идей «мусорных преобразований» в не выполненные и не смогут оказать сколь-нибудь реального кардинального улучшения экологии в России.

Ключевые слова: "Мусорная реформа", Новая коммунальная услуга "0бращение с ТКО", Публично-правовая компания (ППК) Российский экологический оператор (РЭ0), Общества с ограниченной ответственностью (000) региональные операторы, Публичные акционерные общества по обращению с ТKO, мусорные протесты.

и рекультивированных земель составила 545 га. Абсолютный коллапс временно отступил (хоть и ненадолго).

Безусловно, что сама идея необходимости создания наиболее современной передовой мусороперерабатывающей отрасли, была и остаётся давно назревшей и правильной. Но её нынешнее воплощение «с потолка» может, к сожалению, обернуться для страны реальной экологической катастрофой. Происходящее с модернизацией мусорной отрасли оказалось неправомерным и несправедливым, а потому не требует отлагательства. Недовольство и раздражение народа ухудшающейся экологической обстановкой в стране только нарастает. Вопросов, как всегда, больше, чем ответов. А внятных адекватных объяснений и приемлемых решений у правительственных чиновников и депутатов всех уровней 
по ситуации, как всегда, просто нет. Жизнь, когда постоянно генерируются новые идеи и перестраиваются неудачные решения, приведшие к «мусорным катаклизмам», как будто вдруг стала в паузу. В массовом сознании людей постепенно приходит понимание того, что происходящее сейчас с решением «мусорной проблемы» - это грандиозный фейк (Fake-c англ. «подделка», «фальшивка», «обман», «ложь»), созданный на бюджетные деньги кучкой жалких аферистов, проходимцев, авантюристов и хапуг. Иллюзия благополучия, сформированная профильным Министерством природных ресурсов и экологии Российской Федерации (Минприроды РФ) в экстренном порядке, в виде специального приложения (паспорта), которое содержит общую характеристику национального проекта "Экология" на 2019-2024 гг. в состав, которого наряду с другими 10 федеральными проектами был включён в качестве одного из ключевых направлений федеральный проект (план) «Комплексная система обращения с твёрдыми коммунальными отходами (ТКО)» (или “мусорная реформа”)[14] окончательно рухнула.

Вопреки главной идеи указа Президента России от 7 мая 2018 года № 204 [7] и первоначально утверждённого президиумом Совета при Президенте Российской Федерации по стратегическому развитию и национальным проектам [8] варианта паспорта, где чётко предусматривалось создание самой передовой в мире мусорной отрасли с приоритетом переработки и максимальным вовлечением отходов во вторичный оборот Минприрода РФ стала активно навязывать обществу массовое строительство мусоросжигательных заводов (MC3).

Между тем в принятом странами Евросоюза документе «ЕС Таксомания» технология мусоросжигания сегодня уже полностью исключена из разряда экологичных и финансировать её в дальнейшем строго-настрого запретили. Онкология, генетические мутации, увеличение смертности почти на 40\% - вот лишь некоторые из научно доказанных опасных последствий строительства дорогостоящих МС3.

Россия уже сейчас катастрофически теряет население: падает рождаемость, высоки темпы смертности [21]. По воле же Минприроды РФ в ближайшем будущем Россия рискует быстро превратиться в мировую онкодержаву. Профилактика рака и развитие отечественной медицины начинают терять всякий смысл, если наша страна не прекратит идти по пути строительства МСЗ. В условиях сырьевой экономики прозападный российский олигархат и высокопоставленные чиновники под видом патриотов насильно дополнительно навязывают населению ещё одну опасную «Экономику трубы МСЗ» при которой жуликам, ворам, казнокрадам и офшор- но-олигархическому капиталу не нужны образованные, здоровые, думающее и ответственные люди. Офшорной аристократии и сырьевым баронам требуется запуганная, маргинализированная, дебилизированная, покорная и не доживающая до старости челядь. Фактически это созвучно знаменитому высказыванию покойного американского сенатора-республиканца от штата Аризона Джона Маккейна (1936-2018 гг.), что «Россия — это бензоколонка, прикидывающаяся страной. Это клеп-

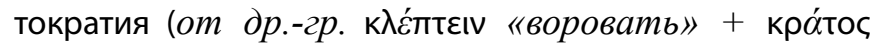
«господство, власть»; буквально «власть воров». Правительство, контролируемое мошенниками, использующими преимущчества власти для увеличения личного богатства и политического влияния, с помощью расхищения государственных средств, и тщзательной имитации с помощьюю СМИ собственно честной службы народу.), это коррупция. Это страна, которая на самом деле зависит только от нефти и газа для своей экономики». Нынешние 146,7 млн. россиян - это лишние рты, издержки и не нужная головная боль для власти. Для обслуживания нефтегазовой трубы и особняков, первоочерёдного удовлетворения аппетитов иностранных потребителей вполне хватит и 20 млн. Тем более, например, что почти треть населения страны, являющейся мировым лидером по запасам и добыче природного газа, остается при государственном «Газпроме» без доступа к голубому топливу. Бензин в РФ продолжает постоянно дорожать, при длительном падении доходов россиян несмотря на то, что является одним из главных экспортируемых товаров. Борьба с мусором в условиях сырьевой экономики постепенно превращается сейчас в беспощадную борьбу за жизнь.

Активное лоббирование на грани утопии и пустозвонства Минприродой РФ вопреки категорическим возражениям учёных-экологов и местных жителей многомиллиардного (за счёт налогов граждан) проекта строительства вокруг Москвы (в Ногинском, Солнечногорском, Воскресенском и Наро-Фоминском районах Подмосковья) сети крупных (каждый завод будет перерабатывать около 700 тысяч тонн отходов в год) МС3 (общая только первоначальная стоимость 124 млрд. руб.) наводит у российских людей искреннюю панику. Провоцирует всё большее число соотечественников бежать под крики «полундра» с тонущего корабля «мусорной реформы» к спасательным шлюпкам. Когда представители Минприроды рассказывают в СМИ о будущих результатах «мусорных преобразований», то до них не хочется дожить, а лучше сразу умереть, чтобы не мучиться.

Настораживает, что на фоне полного попустительства, бесконтрольности и безнаказанности Минприроды РФ со стороны «правоохранительных» органов от последствий за легкомысленные и безответственные 
инициативы по сомнительным «мусорным» проектам, зарубежные «бизнес-партнёры» за «откаты» параллельно активно пытаются продать втридорога России то, что завтра будет вне закона во всех цивилизованных странах. Разумеется «гуманному» Западу, впрочем, как и отечественным «хитрым» толстосумам ради собственного «шкурного» интереса нисколько не жаль жителей Подмосковья.

По авторитетному мнению профессиональных экологов, навязывание населению в тендеме министром Минприроды РФ Кобылкиным Д.Н. и губернатором Московской области Воробьёвым А.Ю. в качестве подрядчика и российского инвестора проекта строительства подмосковных МС3, созданной по указу Президента РФ госкорпорации «Ростех» (через бенефициар-пособника «PT-инвест») и явно в угоду наблюдательному целиком проправительственному Совету этой госмонополии типа «государство в государстве», означает не только банальный реверанс в сторону власти и является важным сигналом лояльности и преданности к власти. Он знаменует, к сожалению, для страны курс на самоуничтожение. Вместо 5-6 ступеней очистки отходящих газов, которые использовались, например, на заводе в Швейцарии, у нас будут задействованы только три. Это означает, что выбросы в воздух подмосковных заводов в 20 раз будут превышать европейские показатели. При этом представители «РТ-инвест» кроме хвастливых заявлений, надувания щёк и дорогостоящих пиар-акций по бездоказательному и наглому утверждению, что будут «чистить подмосковный воздух своими заводами» (?!) ведь ничего реально подтвердить научно не могут. Тем более с таким уровнем зарплат (ниже, чем за кассой в Мак-Дональдсе) рассчитывать на то, что в мусоросжигательую часть отрасли по переработке ТКО придут сильные специалисты, которые будут неукоснительно соблюдать технологический регламент, разумеется, нельзя.

Одновременно очень не желающие официально раскрывать своих имён депутаты Госдумы РФ изо всех сил (видимо за вознаграждение) темпераментно лоббируют поправку в законодательство с требованием отменить действующую сейчас обязательную государственную экологическую экспертизу при возведении всех объектов обращения с отходами, в том числе МС3 и проектов рекультивации свалок-(опасность первой категории), которые больше всего загрязняют окружающую среду. В условиях тяжёлого социально-экономического кризиса и пандемии депутаты вносят законы в Госдуму РФ особенно активно. Конечно, грамотному человеку не трудно отличить, где популизм и попытки набрать очков, а где реальная попытка улучшить ход «мусорной реформы». Согласно изречению одного из величайших ораторов, философов и писателей древнего римского мира Марка Туллия Цицерона (3 января
106 до н. э., Арпинум - 7 декабря 43 до н. э., Формия): «Чем ближе крах империи (в нашем случае «мусорной реформыл»), тем безумнее её законы». И отмена госэкспертизы с помощью лоббизма депутатами крупных игроков, естественно, только повысит риски возникновения техногенных аварий и нанесет серьёзный ущерб природным ресурсам и населению, но фактически освободит исполнителей реформы от ответственности, в том числе уголовной.

Иностранным технологическим партнером по поставкам оборудования была приглашена в октябре 2016 года даже без обязательного конкурса известная швейцарско-японская компания «Hitachi Zosen Inova». Но курс Минприроды РФ на мусоросжигание по технологии данной фирмы оказался совершенно не подготовлен из-за отсутствия в стране раздельного сбора отходов. Он существует только на бумаге. Что наглядно видно на примере того же Подмосковья. Вопреки всем лживым обещаниям подмосковных властей и местных чиновников мусор из разных контейнеров все так же грузится выбранными по конкурсу регоператорами в один мусоровоз. Этот процесс постоянно фиксируют, в частности, жители ногинского кластера (англ. cluster - скопление, кисть, рой-объединение нескольких однородных элементов, которое может рассматриваться как самостоятельная единица, обладающая определённьми свойствами) Подмосковья: Реутова, Балашихи, Никольского, Электрогорска, Электростали, Ногинска и др., которых «обслуживает» регоператор ООО «Хартия» с очень сомнительной репутацией (уставной капитал 10 mыс. руб. при стоимости одной мусороуборочной машины не менее 6,5 млн. руб.). Сжигание именно такого смешанного мусора, по заключению специалистов, как раз и представляет основную опасность. Выбросы при горении неотсортированных бытовых отходов способны, наподобие мощного боевого отравляющего вещества $(Б O B)$ смертельно отравить миллионы людей. Сжигание всего мусора оптом неизбежно приведет к долговременному загрязнению окружающей среды токсичными отходами и геноциду подмосковных жителей. Но даже вывоз этого перемешанного как попало мусора с Нового 2020 года тупо не производится с нарушением графика фактически по всей России. Такая политика Минприроды РФ почти во всём полярна мнению уважаемых учёных-экологов и населения. Запуск в 2020 году в Подмосковье разрекламированного комплекса по переработке отходов за 3,5 млрд. рублей на 450 рабочих мест лишь мизерная часть, которая не в состоянии решить накопившиеся годами проблемы. При сжигании не перерабатываемых отходов будет образовываться токсичная зола высокого класса опасности. И ее тоже нужно будет куда-то девать - то есть строить для ее захоронения новые полигоны. Например, золу с подмосковных заводов реко- 
мендовано увозить на специальный полигон токсичных отходов, который находится в Томске. Отечественные специалисты-экологи, подавляющее число россиян требуют пока не поздно остановить и отозвать все подписанные документы по непродуманному научно и организационно проекту строительства вокруг Москвы сети МС3. Следует заново с нуля начать решать проблему MC3, исходя из первоначальных целей модернизации мусорной отрасли, где главенствующую роль занимала переработка TKO, а не их термоуничтожение. Приоритетной нормой для публично-правовой компании «Российский экологический оператор» (РЭО) [9] и региональных регоператоров должен был стать раздельный сбор и вывоз отсортированного мусора. Российские НИИ уже разработали не одну технологию более безопасного обращения с мусорными «хвостами от сортировки мусора», чем сжигание. По рекомендации экологов, именно сочетание европейского подхода к разумному потреблению с нашими технологиями утилизации «хвостов» и есть лучший вариант выхода из мусорного кризиса. Сомнительные же решения государственного монополиста РЭО, лишь добавляют россиянам скепсиса. На фоне того, что нацпроект «Экология» оказался самым худшим в 2019 году по исполнению, а деятельность РЭО Минприроды РФ организационно направлена лишь на формальное выполнение целей утилизации мусора любой ценой по принципу «после нас хоть потоп» любому здравомыслящему человеку нельзя не понимать, что «гора родила мышь». В проекте федеральной схемы обращения с отходами предполагается к 2024 году строительство и реконструкция 868 «мусорных» объектов (700 новых), включая 148 предприятий по сжиганию мусора общей мощностью 4,3 млн. тонн в год. Минимальная стоимость инфраструктуры оценена РЭО в 101-104 млрд. рублей, без учёта, что в схеме пока не учтены планы «Ростеха» построить еще 25 мусоросжигательных заводов. Дополнительно планируется строительство и модернизация еще 351 полигона (253 нoвblx) и 355 сортировочных станций. Из них 53 предполагают компостирование отходов, 24 - производство альтернативного топлива RDF (Refuse Derived Fuel,- - топливо, которое состоит из оставшихся после сортировки отходов). Современных же предприятий по переработке мусора появится всего лишь не больше десяти на огромную страну. В таком виде планы РЭО противоречат исходным задачам реформы и обновленному на ее старте законодательству перерабатывать к 2024 году не менее 36\% всех отходов. Сжигание и захоронение отходов обоснованно стояли на последнем месте в перечне приоритетов госполитики. Цель реформы запущенной с огромной помпой ради создания современной системы управления отходами и вовлечения их во вторичный оборот кардинально исказилась и не соответствует поставленным планам, справиться с которыми нынешнему Минприроды РФ оказалось определённо не под силу. В предло- женной РЭО изменённой схеме большинство объектов названы «энергетической утилизацией». А по «обновленному» закону энергетическое сжигание мусора приравнено к переработке, хотя это не соответствует даже смыслу русского языка (!). В федеральной схеме РЭО присутствует большое количество новых сортировок, а объемы отсортированных фракций будут направляться не на переработку, а на объекты по утилизации путём сжигания вторичных ресурсов.

Добиться положительного результата с помощью финансово-правовых методов без всестороннего выявления истинных причин, препятствущих реализации «мусорной реформы» и учёта особенностей реальной социально-экономической обстановки при выработке адекватных и эффективных решений, невозможно. Отказ от признания реальности всегда приводит к гибельным последствиям. Попытки преодоления накопившихся «мусорных трудностей» сразу же оголили практически все те недостатки социально-экономической политики страны в целом, которые длительное время удачно маскировались.

Российское государство смертельно поражено критическими для страны причинами: предательством властей интересам общества, когда власть служит не людям, а деньгам, запредельной коррупцией, непрофессионализмом исполнителей и клановостью. Сейчас, когда решения нужно принимать быстро и в условиях дефицита финансирования, а также высокой безработицы (По даннылм Минтруда РФ число офищиально зарегистрированных безработных граждан в России на 1 июня 2020 г. достигло более 2,4 млн. человек) стало видно всю несостоятельность системы управления в целом. Социальные лифты по деловым качествам сломались, подъём происходит только по умению занимать перед начальством позицию льстеца и подхалима. Тысячи молодых реально талантливых специалистов лишены возможности реализовать свои знания и амбиции на госслужбе или крупном бизнесе. Бюрократия и число чиновников зашкаливают: численность работников государственных и муниципальных органов 2,4 млн. человек [15]. Лишь на прибавку в виде индексации зарплат чиновничьего аппарата, по данным Министерства финансов РФ уходит ежегодно 100 миллиардов рублей. По образному выражению первого канцлера Германской империи Отто фон Бисмарка (1815-1898 гг.), обладавшего патриархальным чувством ответственности перед работниками, осуществлявшим социальные программы поддержания доходов, уровня жизни населения, обеспечения занятости, поддержки отраслей социальной сферы, предотвращения социальных конфликтов: «Чиновники - это трутни, пишущие законы, по которым человеку не прожить. Почему у министров жалованье постоянно и независимо от того, хорошо или 
дурно живётся населению? Вот если бы квота жалованья бюрократов колебалась вверх-вниз в зависимости от уровня жизни народа, тогда бы эти дураки меньше писали законов, а больше бы думали».

Совершенно чрезмерны на душу населения количество полисменов (601 mыс. человек или соотношение 1/240) и численность других силовых структур по охране общественного порядка. Сформировавшийся в последние годы милитаризм, привёл к тому, что даже армия всё чаще используется, как инструмент в эгоистических политических играх. В сознании подавляющего числа, находящихся в безнадёжной нищете десятков миллионов россиян (2/3 населения страны доведены до беспросветной бедности и прожсивания в долг), и особенно забытых стариков-пенсионеров и инвалидов, ставших обузой для ослабевшего государства укрепляется понимание бессилия нашей правящей власти перед тем экологическим вызовом, который встал перед Российской Федерацией. Это когда доверяешь человеку, как самому себе, а он вдруг оказывается оборотнем: действует не в твоих интересах.

Растёт чувство обиды на беспомощность государства и его антинародную политику, которую уже не скрыть никакой маской. Народ в своей основной массе перестал доверять правительству, чиновникам, и в принципе государству. Народная память очень сильна и из самых обычных людей никто ничего не забывает об очевидном безумии изобретателей «мусорной реформы». К которым применима верная русская поговорка: «Заставь дурака Богу молиться, он и лоб расшибёт», означающая «навредить из-за необдуманного и чрезмерного старания». В созданной обстановке финансово-правовые решения правительства по «мусорной сфере» оказались оторваны от действительности и напоминают «филькины грамоты», диагнастирующие незначащую или бестолково написанную бумажку. Ситуация с мусорными проблемами зашла в тупик. Законодательная госмашина, которая выстраивалась более 20 лет, в отрыве от реальности дала сбой, стала разваливаться и трещать по швам. Надоела населению. Показала свою несостоятельность в оптимальном решении «мусорных» узких мест.

Неблагоприятная конъюнктура в экологии выявила многочисленные малопригодные на практике изменения в законодательстве. Вскрыла непрозрачность судебной системы в «мусорных» спорах, сильную зависимость её от власти, которая сделала крайне непопулярной нормой нашего времени обращения в суд, даже по незначительным вопросам, которые обязаны решать чиновники на местах. Не объективность и не эффективность совокупности действующих принципов, методов, приемов осуществления правосудия, естественно, не внушает доверия россиянам. По одной и той же проблеме судьи в разных региональных субъектах федерации выносят диаметрально противоположные решения в зависимости от позиции властей на местах. За не соответствие законодательству вынесенных постановлений судьи, как правило, ответственности не несут. Согласно российскому праву, судьи, даже покинув должность, остаются спецсубъектами, на привлечение которых в качестве обвиняемых необходимо разрешение высшей квалификационной коллегии судей. Вместо урегулирования мощных социальных конфликтов относящихся к необоснованному росту суммы оплаты за вывоз и утилизацию мусора, безудержному загрязнению воздуха, отравлению питьевой воды, засорению рек, морей и океанов, вырубке и масштабных пожаров лесов (за последние 40 лет лесов стало меньше чуть ли не втрое) вымиранию сотен видов животных, насекомых, птиц, рыб, варварского истощения природных ресурсов и других фактах, связанных с охраной окружающей среды и здоровья людей судебные инстанции напротив разжигают социальную рознь и дестабилизируют российское общество.

К сожалению, неотъемлемой частью жизни в большинстве регионах России стали постоянные «мусорные» стихийные митинги протеста. Власти пока пытаются купировать проблему, а люди просто хотят действовать в рамках правового поля. Поэтому активисты регулярно подают заявки на проведение митингов, получают отказы, подвергаются арестам накануне протестных мероприятий, но продолжают при этом вести себя как законопослушные граждане. Экологический протест будет и дальше развиваться, и даже может выйти на новый уровень за счет общего недовольства граждан, вызванного экономическим кризисом. Всё это свидетельствует, что действительно существуют серьезные риски возникновения уже всероссийского митинга протеста в связи с резким ухудшением одновременно экологической и экономической обстановки в стране [23]. Разработчикам «мусорных» проблем давно настала пора задуматься о собственных просчётах, переосмыслить свои предложения и принципы, чтобы прекратить гнаться за чемто несбыточным. Не рассчитывать на великий русский авось и его ужасающие последствия.

Важным сравнительно новым фактором тормозящим финансово-правовую модернизацию «мусорной» индустрии является тот факт, что информация, как пища для ума, стала активно использоваться в том числе властью, для вбросов дезинформации с целью усилить дезориентацию населения. Разговоры о «мусорных достиженияХ» — это попытка властей создать позитивную повестку в условиях кризиса.

Как нельзя лучше отражает наши реалии меткое четверостишие, не потерявшее актуальности и по сей день 
русского поэта-патриота Демьяна Бедного (настоящее имя Ефим Алексеевич Придворов 1883-1945 г2.) «Больше слухов! Больше мути! В ход любую дребедень! Дичь нелепую до жути преподносят каждый день» [16]. В головах современных людей накопилось много «мусора». Среди которого деструктивные и ограничивающие убеждения, нелепые запреты, бессмысленные долженствования. Иллюзорные, нереалистичные представления об "устройстве» мусорной реформы, о мнимых способах достижения позитивных результатов предлагаемых преобразований, делания для этого чего-либо.

Многочисленные telegram-каналы активно используются, чтобы создавать другую виртуальную реальность, не имеющую никакого отношения к действительности. Сейчас с помощью распространения информационных вирусов идёт борьба за умы. Telegram-каналы превратились в фабрики фейковых новостей. Их цель погоня за хайпом («Хайп» (hype) с англ. «обман», «назойливая реклама», «возбуждение», «раскрутить»или «раздуть»), желание поинтриговать, применять все известные инструменты и средства манипуляции населением, стремление создать проблему там, где она не существует. Фейкомёты-иммитаторы умело распространяют за деньги, в том числе из бюджета, ложь, оказывающуюся в итоге "правдой" в нашем окончательно слетевшем со всех катушек мире.

В тоже время, из-за огромной боязни и категорического нежелания большинства чиновников и властей признать важность открытого диалога с обществом коммуникации власти и социума практически, по-прежнему, полностью в экологической сфере не работают. Вместо этого на деньги налогоплательщиков организована путём бесперебойного зомбирования через систему СМИ и прежде всего телевидения пропаганда тотальной лжи о реальном положении дел (промывка мозгов), в том числе с якобы «успешной» реализацией «мусорной реформы». Чтобы люди поверили в красивую сказку о «мусорных преобразованиях».

Государство глухо, как пень: докричаться до эверестовских вершин власти простым людям не вмоготу. От их имени могли бы достучаться честные, смелые и независимые СМИ. Но подавляющее большинство СМИ уже давно в руках приближённых к власти толстосумов-приватизаторов государства. СМИ заняты получением прибыли за счёт платных публикаций и рекламы. В итоге государственная пропагандистская машина, в последние годы, как и система российской официальной статистики стали систематически и очень масштабно сдавать объективные позиции в сторону фальсификации. Мониторингу же общественного мнения по поводу «мусорной реформы», полученному с помощью опросов Всероссийского центра исследований общественного мнения (ВЦИОМ) большая часть населения уже совсем не доверяет. Информационное уменьшение актуальности «мусорного шока» только искусственно и временно снижает беспокойство населения до размера, не связанного с реальной опасностью.

Организованные властью общественные структуры, такие как: Общенациональный народный фронт (OHФ), Общественная палата $(O П)$, Совет при Президенте Российской Федерации по развитию гражданского общества и правам человека (СПЧ) являются по сути марионеточными и ручными. Служат для облегчения принятий финансово-правовых решений режима плутократии (др.-греч. плог̃тос-богатство, кра́тос-правление. Политический режим, при котором решения государственных органов определяются волей небольшого круга группировок богатых людей). Они иногда пробивают глухоту власти и медийную блокаду, донося до верхов немногое из того, о чём говорят и думают люди, но только в границах, определённых их, предназначением. Причислить же их к гражданскому обществу не возможно так, как данные организации возникли не «снизу», а по указанию, спущенному «с самого верху». Поэтому и отношение к назначенным властью отрядам из «плебеев» с особыми правами и режимом благоприятствования двойственное. Они, безусловно, выполняют важную миссию, выступая в качестве своеобразной перегородки между государством, как бездушной машины, и гражданами, интересам которых они призваны служить, но не могут при всём стремлении. В результате недовольство народа быстро ухудшающейся экологической обстановкой в стране только нарастает.

Предполагалось, например, под контролем общественных структур разработать и создать адекватную современным требованиям федеральную схему обращения с ТKO, утвердить программу востребованных мер поддержки инвестиционных проектов в регионах, разработать механизмы государственной без дополнительных поборов с граждан поддержки региональных операторов в случае их банкротства. Внедрить новую концепцию расширенной ответственности производителей (РОП) по принципу «загрязнитель платит». Обеспечить меры по разграничению экологических обязательств между производителями упаковки и предприятиями-переработчиками, а также усилить методы контроля за утилизацией, пересмотреть механизм отбора объектов при включении в план реализации федерального проекта. Планировалось, что решения о строительстве инфраструктуры ТКО будут осуществлять с учётом существующих мощностей по обработке и утилизации ТКО в регионах. Однако выполнение большинства проектов затормозилось. Одной из ключевых причин неисполнения стала слабая работа регионов по подготовке проектно-сметной документации для воз- 
ведения объектов капитального строительства в рамках нацпроекта. Не удалось интегрировать работу профильных ведомств и субъектов с учётом системных подходов к «мусорной проблеме».

Необходимо отметить, что до 1 января 2019 года, когда в России официально объявили начало «мусорной реформы» процессы сбора, вывоза, хранения и переработки мусора уже регулировались, принятым в 1998 году Ф3 № 89 - ключевым в сфере обращения с отходами. Однако тяжелейший экономический кризис 17 августа 1998 года (чёрныц̆ понедельник) надолго затормозил исполнение большинства замыслов Ф3 № 89, с его последующими многочисленными изменениями и дополнениями[6,7]. Например, первые экологические сборы, по данным Гринпис, начали поступать в казну лишь через пятнадцать с лишним лет - в середине 2010-х. Ресайклинг (om англ. Recycling-nереработка отходов) и раздельный сбор мусора стали возвращаться в мейнстрим (англ. mainstream-«основное течение»-nреобладающее направление, массовые тенденции) вообще только в 2019 году.

Между тем, объективно следует признать, что в советское время действовала достаточно стройная система сбора и переработки мусора, которую многие считали одной из самых передовых в мире для своего времени. Сбор мусора, не только в Москве и крупных городах, но и по всей стране, в советские годы был организован эффективно и нареканий не вызывал. Стеклянные бутылки возвращали в специальные пункты приема стеклотары, пластиковых бутылок еще не было, да и в целом количество пластика и полиэтилена до 1990-х было несопоставимо с нынешним. Металлолом и бумагу собирали не только пионеры и школьники. Исправно работали точки приема утильсырья, макулатуру отдавали, чтобы получать в обмен дефицитные книги. Мусор, таким образом, предварительно сортировался и на свалки его поступало в десятки раз меньше, чем сейчас.

Однако, в результате волюнтаристического уничтожения крупнейшей державы мира СССР путём подписания 8 декабря 1991 года Беловежского соглашения тройкой западных агентов, которые тем самым незаконно проигнорировали результаты (более $70 \%$ населения Советского Союза высказались за сохранение СССР) Всесоюзного референдума 17 марта 1991 года на смену советскому социуму с его общенародным социалистическим наследием в начале 90-х пришло потребительское общество олигархического госкапитализма, характеризующееся индивидуальными идеалами, упадком нравственных ценностей и бездуховностью, безумной жаждой исключительно только наживы любой ценой. Согласно результатам исследования экспертов московской консалтинговой фирмы «ViLASS», сегодня примерно три процента самого обеспеченного населения России владеют почти 90 процентами всех финансовых активов страны.

Если судить не по громким фразам, не по стратегиям и декларациям, а по фактическому положению дел, то в отношении социального неравенства Россия чётко проводит неолиберальную экономическую политику одним из определяющих проявлений которой бесспорно была чубайсовская приватизация. Конечно, современные штатные идеологи, заполняя головы путаными идеями нынешнему молодому поколению, сознательно с помощью домыслов стирали из памяти многое положительное, что достиг советский народ и о чем следовало бы всегда помнить в исчезнувшей стране. Разумеется, в Советском Союзе, как и в любом государстве, естественно, были недостатки. Но ещё остались люди, которые родились, выросли и жили в советское время и воспринимают нынешнюю провальную «мусорную реформу» с убедительным чувством того, что в СССР такого безобразия просто быть не могло. Им больно наблюдать за деградацией нашей когда-то великой державы. Ситуацию с потерей СССР и утратой напрочь нынешней властью способности решать крупные мегапроекты в интересах общества, а не отдельных олигархов предельно ясно выразил член правления Союза писателей России поэт Николай Зиновьев (1960 г.p.): У карты бывшего Союза, с обвальным грохотом в груди, стою. Не плачу, не молюсь я, а просто нету сил уйти. Я глажу горы, глажу реки, касаюсь пальиами морей. Как будто закрываю веки несчастной Родине моей[19].

Созданная в советское время схема сбора и переработки мусора была совершенно бездумно разгромлена. Прекращение повторного использования макулатуры и сбора вторсырья, наступивший век массового применения предметов из многочисленных видов пластмассы (одноразовая посуда, бутылки, плёнка, пакеты, мебель, игрушки и т.д.) [24], новая культура потребления увеличили количество мусора в разы. Переход от федерального контроля на региональный уровень, нарушение иерархической системы привели к ситуации, когда разрушились этапы сбора и последующего использования отходов.

Из-за отсутствия в достаточных масштабах сортировки мусора в Россию в условиях сильного тренда абсолютной зависимости детей и внуков российских государственных чиновников, депутатов всех уровней от иностранного гражданства (вида на жительство), имеющихся счетов в зарубежных банках, наличия в других странах (Великобритания, США, Германия, Франция, Италия, Испания и т. д.) дорогой недвижимости каждый год за валюту стали ввозиться из-за границы миллионы тонн отходов для переработки, чтобы загру- 
зить отечественные мусороперерабатывающие заводы. Свой же мусор практически нигде не перерабатывается. Ежегодно всего лишь 5 млн. тонн пластика, бумаги и древесины обретает «вторую» жизнь. Все остальное (не менее 65 млн. тонн) оседает на свалках и полигонах, часто по-прежнему незаконных [23].

Жестокая реальность сегодняшнего дня на фоне каждодневных техногенных катастроф, на которые уже никто не обращает внимания, показывает всю эфемерность красивой картинки о «мусорной реформе», оказавшейся пустым блефом. Ситуация с отходами становится невыносимой - в разных городах контейнеры переполнены, на улицах неконтролируемо растут свалки, которые никто не убирает, во дворах мусором завалены даже проезды для автомобилей, отмечаются серьезные проблемы с вывозом отходов.

Граждане дышат засорённым сверх установленных законом норм воздухом, опасаются распространения грызунов, насекомых и новых инфекций типа вируса CoViD-19 и его модификаций. Пустая говорильня о мнимых достоинствах «мусорной реформы» только озлобляет народ. Отмечены многочисленные случаи поджогов мусорных куч.

Предложенный вариант расхайпированной «мусорной реформы» вытесняет здравый смысл, оказался нежизнеспособным, оторванным от действительности, увяз в коррупции и массовых финансовых поборах с нищего в своей основной массе населения. Мы сейчас наблюдаем её полный и безоговорочный крах.

Всё это вводит граждан в полное непонимание и абсурдность происходящего. Драма с нашим вороватым чиновничеством продолжает накаляться, но завуалированно. Некомпетентные губернаторы, министры, которые определяют политику нашего государства, не хотят брать на себя какую-либо ответственность, и замены им нет. Правящие сегодня российские чиновники будто стремятся своей деятельностью подтвердить актуальность язвительных афоризмов предыдущих времён известного русского писателя-сатирика, Рязанского и Тверского вице-губернатора М.Е. Салтыкова-Щедрина (5 (27) января 1826-28 апреля (10 мая) 1889 г2.): «Российская власть должна держать свой народ в состоянии постоянного изумления»; «Если на Святой Руси человек начнёт удивляться, то он остолбенеет в изумлении и так до смерти столбом и простоит»; «Если я усну и проснусь через сто лет, и меня спросят, что происходит в России, я отвечу: пьют и воруют» [27].

Построенная в рамках национального проекта «Экология» модель «мусорной реформы», где под красивой ширмой так и осталась самая обычная схема, по выкач- ке денег из карманов россиян находится в системном кризисе и абсолютном хаосе. Агония мусорного бизнеса оказавшегося в прострации, будет просто искусственно продлеваться за счёт налогоплательщиков. Только в 2020 году на обеспечение бесперебойного вывоза мусора субъектам Российской Федерации намечено выделить дополнительно более 8,1 млрд. рублей за счёт налогов с населения.

Сегодня нужно говорить уже не о поддержке «мусорной реформы», а о её реанимации и коренной модернизации. Всё это свидетельствует о неадекватности принимаемых в правительстве решений, приведших к порочности и исчерпанности утопической модели «мусорной реформы», спровоцировавшей резкий рост финансовой нагрузки на население без достижения результатов.

Поскольку мыльный пузырь иллюзии «мусорных преобразований» имеет свойство неминуемо лопаться, это бесповоротно ударит по отечественной экономике, загоняя Россию в болото экономической недоразвитости. Народу не нужны предлагаемые создателями «мусорной отрасли» всевозможные надуманные фейковые около государственные «прокладки», которые будут распределять финансовые резервы в бюджете, попутно их разворовывая. А тот факт, что создатели «мусорной реформы», принимая определенные правовые нормы, не предвидели такого развития событий, наверное, свидетельствует об их сомнительных прогностических талантах.

Неудивительно, что действия организаторов «мусорной эпопеи» давно стали мемом (единица информации, запавшая в память людей, ставшая популярной) и вызывают у граждан одно лишь недоумение и раздражение. Как известно, «зарабатывать» наше государство, кроме как от добычи и продаже сырья не умеет и живёт на налоги, собранные с граждан. Поэтому «Мусорное шоу» на деньги налогоплательщиков превратилось в руках его инициаторов и исполнителей в идеальный инструмент паразитирования на бюджете страны и «законного» совершенно безнаказанного обкрадывания оболваненного пропагандой населения, через систему жилищно-коммунального хозяйства (ЖКX) под охраной «правоохранительных» органов. Сохраняется накопленная задолженность в 550 млрд. руб. со стороны тех граждан, которые вряд ли с ней когда-либо расплатятся. Для решения проблемы не выплачиваемых долгов государству за жилищно-коммунальные услуги (ЖКУ), возможно, следует пойти на их списание раз в три года.

Надуманное прославление властями «мусорно-собирательной» деятельности регоператоров в структуре ЖКУ и Фонда ЖКХ ежегодно обходится россиянам 
в огромные невосполнимые и совершенно непроизводственные траты. Это реально грозит ЖКХ эффектом «прорыва плотины» от накопившихся претензий, особенно по самой неоднозначной новой строке в квитанции за ЖКУ - коммунальной услуге «Обращение с ТКО». Россияне массово игнорируют неправильно начисленную плату за вывоз мусора. Общий долг, например, за вывоз бытовых отходов только в ряде подмосковных городских округах (Мытищзи, Одинцуово, Ленинский, Истра, Красногорск и Домодедово), обслуживаемых лишь одним региональным оператором, входящим в структуру «РТ-Инвест» достиг 3 млрд. руб. По мнению авторитетного эксперта, профессора Международной академии маркетинга и менеджмента (МАМАРМЕН) Ю.Ф. Нардюжева одной из главных причин значительного сокращения поступлений платежей в ООО регоператоров по данной коммунальной услуге стало резкое несоответствие увеличения стоимости утилизации TKO, вызванное несовершенством «мусорной реформы» падению доходов населения. «Мусорная реформа» выжата насухо. Коронабесие лишило людей средств к существованию, а многие бизнесы просто уничтожены. Российское государство, по сути, запретило многим гражданам РФ жить. С каждым месяцем долги населения за коммунальную услугу «Обращение с ТKO» неуклонно растут. Катастрофическая ситуация с невозможностью оплаты населением неоправданно завышенной коммунальной услуги «Обращение с ТКО» приведет к неизбежному коллапсу мусорной отрасли [23].

Введение режима самоизоляции, перехода на удалённую работу, дистанционное обучение, резкий всплеск безработицы открыли невиданную ранее более эффективную форму выражения протестных настроений граждан через онлайн-митинги с помощью сервисов «Яндекс. Карты» и «Яндекс. Навигатор». Масштабные, во много раз гораздо многочисленнее обычных акций протеста виртуальные митинги в Ростове-на-Дону, Москве, Санкт-Петербурге, Екатеринбурге, Красноярске, Нижнем

Новгороде оказались несравненно более мощным рабочим инструментом, который власти уже не могут разогнать и подавить с помощью полисменов, ОМОНа или Росгвардии.

Экологический предмет связанный с проблемой мусора превратился сейчас в острый политический вопрос. Тем более, что в условиях огромного количества населения живущего за чертой бедности (В 2020 году «минималка» /МРОТ/ составляет по России 12130 руб. или 174\$. Что ниже чем даже в африканских странах: Габон 270\$, ЮАР 256\$, Марокко -310\$) финансовые возможности налоговых пополнений бюджета за счёт граждан достигли предела и поэтому государство не сможет основательно, как было первоначально офи- циально заявлено, инвестировать денежные средства в реформирование мусорной отрасли.

В России преимущественно сейчас действует захоронительный вариант утилизации мусора. Он самый выгодный для частных предпринимателей так, как требует минимальных вложений. Но даже в такой огромной по территории стране, как Русь, количество земельных участков, где можно открыть свалку, не бесконечно. Поэтому доминирующий первоначальный смысл нынешней реорганизации состоял в том, чтобы теперь мусор по большей части не хоронить, а перерабатывать и лишь, в самом крайнем случае, сжигать.

Но менять профиль и уходить в переработку захоронительному бизнесу затратно, хлопотно и нескоро окупится. Ведь для этого необходимо строить собственные перерабатывающие предприятия, снабжать их обязательно отсортированными отходами, искать сбыт продукции. К тому же свалочным мусорным бизнесом практически во всех регионах традиционно занимаются люди с «криминальной» субкультурой и с соответствующим поведением, которые не могут, а потому и не хотят организовывать современный бизнес. Они осознано тормозят раздельный сбор мусора и его последующую переработку.

«Мусорная реформа» запустила передел мусорного рынка, в интересах крупных олигархов и высокопоставленных функционеров, приближенных к власти, их детей и близкого бизнес-окружения. Вместо двух союзников России: её армии и флота в бытность императора Александра III Миротворца (1845-1894 г2.) теперь только на борьбу с мусором есть, аж целых три. Соратниками государства по борьбе с мусором назначенными властью по их же просьбе стали: экс генеральный прокурор РФ Чайка Ю.Я., герой России (2019) Чемезов С.В. и герой труда (2020 г.) Ротенберг А.Р. И это не считая целой компании «Мусорных смотрящих», которым современные единомышленники России решили передоверить экологическую безопасность страны. Новые мусорные «короли» ретиво, словно навозные мухи слетелись из всех своих схронов на милый их нутру запах гниения и разложения. Сразу с 1 января 2019 года они стали молниеносно собирать с населения повысившуюся в несколько раз, а в некоторых регионах в десятки раз из-за неуёмной жадности плату за коммунальную услугу «Обращение с ТKО» через учреждённых ими в форме ООО регоператоров. Среди VIP-мусорщиков: Игорь Юрьевич Чайка (младший сын бывшего генпрокуроpa PФ), Игорь Аркадьевич Ротенберг (сын бизнесмена из ближайшего окружения президента РФ) Андрей Евгеньевич Шипелов (аффилированный партнёр владельияа «Ростеха» Сергея Чемизова и Аркадия Ротенберга. Через «РТ-Инвест» и по транспортной 
системе «Платон с её «налогом Ротенеберга», который собирают с большегрузных машин», зять «мусорного» пахана Нижегородской области г-на Агафонов В. Е.). Сами же заводы появятся только через 2-3 года, и то с сомнительными показателями по нормам выброса вредных веществ. Минприроды РФ отдала практически полностью на откуп приближённому к власти бизнесу всю мусорную отрасль в стране и, по сути, дала ему карт-бланш. Соблазн заработать твёрдую валюту на твёрдых бытовых отходах привёл в мусорный бизнес и сына главы Сбербанка Германа Грефа Олега, детей экс-главы ВЭБа Владимира Дмитриева - Степана и Павла. Компания ООО «Чистая Логистика» имеет прямое отношение к сыновьям главы Сбербанка Германа Грефа и вице-президента Торгово-промышленной палаты, экс-главы ВэБа Владимира Дмитриева. «Чистая Логистика» на 50\% и 40\% принадлежит Степану и Павлу Дмитриеву соответственно, еще по 5\% Олегу Грефу и гендиректору компании Валерию Есауленко. Очередь эта длинная и разношёрстная. Она постоянно растёт. Ведь исполнители реформы так давно привыкли получать космически много, ничего не давая взамен.

В условиях быстрого движения к экономической катастрофе даже криво устроенное государство не захочет и не сможет принять на себя обязательства по спасению бессмысленного мыльного пузыря. Тем не менее, совершенно очевидно, что разработчики «мусорной реформы» не захотят лишиться контрактов, откатов, распилов на миллиарды рублей в год, всего лишь потому, что у бюджетной коровы иссякло вымя. Наш олигархат взращен не конкурентным производством, а приватизированным госимуществом (воровством) и основная статья, пополняющая их кошельки это бюджетные деньги, в том числе и пенсионные вклады граждан. Следовательно, ждать добровольного самоустранения не приходится. Изречение греческого комедиографа Эпихарма (540-450 г2. до н. э.): «Рука руку моет, а плут плута покроет», связанное с сокрытием нравственной нечистоты и переплетением олигархата и власти актуально по сей день.

Но пока все их ООО в ранге выбранных по конкурсу региональных операторов присутствуют даже не на всех этапах технологической цепочки, а только вывозят, частично сортируют, депонируют. Хотя бизнес-модель предполагает, их обязанность заняться в первую очередь переработкой, когда создадут необходимую инфраструктуру, нарастив достаточные объёмы поступающего сырья.

Благими намерениями создателями «мусорного проекта» предполагалось, что вновь привлекаемые переработчики мусора в лице региональных операторов с помощью властных структур заберут благодаря изме- нениям в законодательстве у прежних захоронителей существенные объёмы. На деле же появилось новое звено по отъёму денег у населения дополнительно к УК. Предыдущие «мусорные» конторы, как были так и практически остались и стали субподрядчиками у регоператоров-подрядчиков вместо УК. Или сами по обоюдному согласию с региональными органами власти стали по «конкурсу» регоператорами.

Известно, что во всём мире давно и ожесточённо идут упорные финансовые бои за рынок вывоза и переработки мусора. Бизнес хоть и с душком, но «Деньги не пахнут» (лam. pecunia non olet)., согласно крылатому выражению римского императора Веспасиана (І век), который ввёл налог на общественные уборные.

Свойства денег не зависят от того, как они были заработаны. К тому же мусор - очень перспективный бизнес, поскольку фактически «вечный», как и похоронный.

Высокие тарифы на уборку и утилизацию отходов для населения значительно повысили привлекательность «мусорной экономики». Тем более что помимо постоянной абонентской платы населения за «Обращение с ТКО» эта создающаяся индустрия будет постоянно пополняться правительством крупными финансовыми инъекциями из государственной казны (за счёт налогов с населения) по разделу «Экология». До 2024 года на развитие мусорной отрасли и создание инфраструктуры по обращению с ТКО предусмотрено выделить до 104 млрд. рублей. Кроме того, 190 млрд. рублей уже заложено как затраты региональных властей и бизнеса. Всего же в ближайшие 10 лет вывоз и утилизация бытового мусора обойдется жителям России в 2 триллиона рублей. При таких огромных финансовых вложениях власти рассчитывали, что уже в ближайшее время создаваемая заново «мусорная» отрасль сможет конкурировать с такими «монстрами», как «РЖД», «Газпром» или «Роснефть».

Однако в России исполнители реформы не научились грамотно и эффективно распоряжаться мусором, в прямом смысле слова выжимая из него по максимуму, чтобы страна могла бы успешно соскочить с «нефтяной иглы». Из-за пробелов в соответствующем законодательстве, правовой неопределённости и неэффективного регулирования этой сферы мы оставляем на свалках и обочинах дорог миллиарды рублей в мусорном эквиваленте.

У исполнителей реформы отсутствуют энергетика и достаточные знания того, куда идти и что делать. Ни один регион в России оказался не готов к мусорной реформе, разработанной без учёта причин препятствующих её реализации. Нет мощностей, нет инвесторов, нет полигонов. Все понимают: Корову надо было вначале кормить, а только потом уж доить. Но эта аксиома не для 
исполнителей реформы. Доить послушное запутанное и инфальтильное население они будут пока оно не сможет окончательно и бесповоротно оплачивать налоги, штрафы, «обращение с ТКО» и ЖКУ, кредиты. Проводить реформу в этих условиях организационно было не только преждевременно, но и опасно.

Неоднократные заявления министра Минприроды РФ Д.Н. Кобылкина СМИ о необходимости постоянной подпитке регоператоров за счёт бюджета, который формируется из непомерной финансовой нагрузки с населения свидетельствуют о крайней профессиональной слабости чиновника федерального уровня (!), который даже не осознаёт насколько в настоящее время в бедственном положении находится население нашей страны. Введение жестких ограничений в рамках борьбы с коронавирусом, в России только усилило и без того масштабный экономический кризис, рост безработицы и увеличение объёма совокупной задолженности населения по банковским кредитам до 17,02 трлн. руб.(!). По данным Национального бюро кредитных историй, работающие россияне в среднем отдают банкам уже четверть своей зарплаты (24,6\%). Общая же сумма всех долговых обязательств россиян по экспертной оценке профессора МАМАРМЕН Ю.Ф. Нардюжева составляет более 55 триллионов рублей. Такую сумму ни один бюджет не потянет.

Непробиваемая броня чиновников Минприроды РФ в виде действий, которые они предпринимают, прикрываясь часто ведомственными, не имеющего правового смысла бумагами или приказами, не прошибаема и прежде всего потому, что все усилия населения по восстановлению справедливости будут разбиваться о уже совершившийся факт. По правильному представлению граждан случившееся «с мусорной реформой» следует однозначно расценивать, как акт вандализма и движения назад почему-то признаваемого разработчиками «мусорной» эпопеи справедливым действием. Зная это заранее, налогоплательщики стали предпринимать что угодно, лишь бы не допустить случаи издевательства над здравым смыслом. Но эти манипуляции, как и связанные с ними носители абсурда - регоператоры, необыкновенно живучи и неуязвимы из-за поддержки коррумпированной власти. Что бы вы ни делали, они останутся на своих местах, а вы, даже если докажете свою правоту, не вернете утраченного - ни духовного, ни материального. Изобретатели реформы наслаждаясь бессилием и переживаниями россиян, будут показательно спокойны и лишь в случае, если вам удастся зацепить их болезненную гордыню, могут взорваться, показав свое никчемное нутро, под прикрытием любимого ими бездоказательного слогана - «Для вашей же пользы».

Деятельность выбранных по конкурсу региональных операторов в виде ООО не внушает оптимизма. По сво- ей сути идея их создания в нынешней социально-экономической обстановке в стране является неправильной и ошибочной, обречённой тупиковой ветвью развития. Уже есть 11 субъектов, где образовались риски банкротства. Россия отстаёт по объемам переработки мусора даже от Пакистана. Огромная отрасль с большим экономическим и социальным потенциалом регулируется сырым законодательством, в ней царит беспорядок. На всех уровнях отсутствуют прозрачные инвестиционные модели построения в стране новой отрасли. Граждане не получают качественного сервиса, да и для самих властей проблема мусора - одна из самых насущных и трудно решаемых вне зависимости от размера населенного пункта. На плечи добросовестных граждан необоснованно перекладываются финансовые проблемы неэффективных региональных операторов. Гарантом стабилизации оказания услуг населению в сфере обращения с отходами в многочисленных неблагоприятных сценариях, связанных с работой региональных операторов в экстренных случаях, как правило, выступают только дополнительные поборы с граждан.

Полномочия и ответственность за всю цепочку движения мусора от баков до полигонов в каждом регионе возлагаются на региональных операторов-монополистов. Управляющие компании (УК) принудительно лишены этой функции. С момента самого начала работы региональных операторов от граждан сразу стало постоянно поступать большое количество претензий о тех или иных многочисленных спорных моментах, которые необоснованно повышают стоимость новой коммунальной услуги, в том числе, даже если она совсем не оказана. Это значительно ослабляет авторитет власти, которая, как выясняется, совершенно бессильна, а потому и не желает добиться выполнения честных правил. Граждане в массовом порядке намеренно отказываются выполнять явно «сырые» законы, которые они справедливо считают несправедливыми. Народ все никак в толк не возьмёт, как рассчитываются цены на услугу за вывоз мусора, почему у людей нет выбора мусоровывозящей компании (конкуренция), почему и с производителей товаров берется утилизационный сбор и с граждан и организаций взимается оплата за вывоз мусора одновременно (двойная оплата за одно и то же получает(я), почему владельцы частных домов должны платить за вывоз мусора в том же объеме как и все, тогда как подавляющий объем доходов они утилизируют самостоятельно, сжигая мусор в печи или зарывая в компостной яме на своем же участке, почему надо платить за вывоз мусора в жилище, в котором не проживает?

Региональные операторы построили свой бизнес с помощью чиновников исключительно на завышенных тарифах, пользуясь своей монополией на местах и мягко сказать «законно» обирают народ. Тариф поступает ав- 
томатически, а раздельный сбор требует вложений для развития. Им проще вообще ничего не делать, а лишь обеспечивать транспортировку мусора на полигоны. Платить за услугу «Обращение с TKO» граждан обязали согласно тарифу, утвержденному руководством региона. Тарифы должны иметь под собой грамотное экономическое обоснование. Как обычно, таковое отсутствует или содержит ошибки в расчетах. Поэтому такой тариф является незаконным. А, следовательно, и взимание платы по нему также противоправно. Уже имеются решения судов о признании тарифов необоснованно завышенными (Кировский облсуд, дело № 3a-13/2019; Самарский облсуд, дело № 3a-1030/2019). Это означает, что местным региональным операторам всё же придётся сделать перерасчет суммы.

«Обращение с ТКО» стало коммунальной услугой, которая выведена из графы «Содержание ЖФ» в извещениях ЖКХ. Для собственников жилья это означает, что платить за услугу тоже следует уже не УК, а региональному оператору. Возмездный договор на оказание коммунальных услуг согласно пункта 148 (1) Постановления Правительства РФ от 06.05.2011 N354 (Правила оказания коммунальных услуг)[13] должен быть заключен в письменной форме с указанием условий оказания услуги. Также договор считается заключенным, если Вы хотя бы раз оплатили услугу. Это называется совершением конклюдентных действий. Договор в этом случае считается заключенным со дня первой оплаты по предъявленной Вам квитанции. При этом для новой коммунальной услуги «Обращение с TKO» перестало иметь значение, был ли фактически подписан письменный договор между двумя сторонами: владельцем жилья и регоператором. Согласно другому в угоду регоператорам Постановлению Правительства РФ от 12.11.2016 № 1156 договор на вывоз мусора признается заключенным с жителями по истечении 15-ти рабочих дней с даты размещения оператором публичной оферты на своем интернет-сайте. Т.е. если собственник «бумажный» договор не подписывал, это не освобождает его от обязанности платить за вывоз мусора[12].

Но, в тоже время, владелец жилья не обязан по Конституции РФ оплачивать одну и ту же услугу дважды[1]. Напротив, именно УК должны были исключить из платы на содержание жилья строку за вывоз ТКО. В том случае, если этого не сделано, жильцы вправе пожаловаться в Жилищную инспекцию или в прокуратуру по факту незаконного взимания платы за услугу, которую фактически оказывает уже другая организация. Однако перерасчёта УК под различными предлогами не делают. Например, в Подмосковье и других регионах собственников жилья «гоняют» по кругу. Чтобы незаконно присвоить деньги плательщиков УК в столичной области выдвигают абсурдное «оправдание» многомиллиардному мошенничеству.
Поскольку деньги за одно и тоже с населения собирают не они, а аффилированный посредник ООО «МосОБЛЕИРЦ». А эта частная запятнанная многочисленными махинациями и погрязшая в коррупции подмосковная контора «отфутболивает» плательщиков обратно к УК.

Мусорный театр абсурда представлен также тем, что пунктом 148 (35) правил 354 установлен порядок перерасчета при временном (свыше 5 дней подряд) отсутствии жильцов только в случаях, когда начисление за ТКО осуществляется исходя из количества проживающих граждан. В результате в одних регионах или муниципальных образованиях, где плата рассчитывается исходя из количества постоянно или временно проживающих в таком жилом помещении перерасчёт осуществляется, а в других, где плата начисляется, исходя из площади жилого помещения перерасчёт не производится. Это приводит к тому, что в двух одинаковых по площади квартирах, в которых никто не проживает в первом случае плату за коммунальную услугу «обращение с TKO» регоператор с собственника не берёт, а с другой пытается получить да ещё с неустойкой, т.е. фактически «за воздух». В данной ситуации финансовое законодательство загнало само себя в угол. И в результате оказалось находящимся в тупиковой ситуации тотального отрицания регоператорами сущности права, когда граждан насильно превращают в финансовые и психологические жертвы произвола властей.

Например, согласно Распоряжению Министерства экологии и природопользования Московской области от 09.10.2018 г. N607-PM, плата за коммунальную услугу по обращению с твердыми коммунальными отходами начисляется собственникам в Подмосковье исходя из площади жилого помещения и в качестве расчетной единицы принимается норматив накопления ТКО на 1 м² $^{2}$ жилплощади. Поэтому в столичной области и тех регионах, где местными властями установлена коммунальная услуга «Обращение с ТKO» из расчёта м $^{2}$ пересчитать плату за время отсутствия очень сложно и только через суд, поскольку разработчики непростительно и умышленно «забыли» предусмотреть в законодательстве порядок перерасчёта и не разработали подходящих формул. Представленные в связи с временным отсутствием потребителя в жилом помещении доказательства подтверждающие несение собственником и членами его семьи расходов за пользование данной услугой в другом субъекте Российской Федерации, например, в Москве в расчёт регоператором, в частности, ООО «Хартия» не принимаются. Хотя услуга «Обращение с ТKO» уже не относится к разряду общедомовых.

В связи с чем приписки по коммунальной услуге «Обращение с ТКО» из расчёта м $^{2}$ при отсутствии проживающих сродни вооружённому ограблению. 
Сам по себе факт отсутствия в нормативных актах методики перерасчета не является основанием для ущемления прав истия, как потребителя ЖКУ, проживаюшего и зарегистрированного не в Московской области, а в Москве или другом регионе РФ. Неубедительные ссылки первого заместителя директора ООО «Хартия» Д.А. Иванова на ведомственное письмо Министерства строительства и жилищно-коммунального хозяйства РФ № 1156-ОД/06 от 18.01.2019 г. не имеют юридической силы, поскольку отражают только весьма спорное мнение данного министерства, а не закон [23]. Поскольку именно исполнительная власть до сих пор не утвердила методику перерасчета платы за спорную услугу, из-за чего нарушаются права собственников, как потребителей жилищно-коммунальных услуг, то эта власть (персональные лица) и должна нести конкретную финансовую ответственность. Ведь каждый грамотный человек знает, что любое число, вплоть до бесконечности при умножении на ноль всегда даёт только ноль.

Тем не менее, региональный оператор 000 «Хартия» в погоне за незаконной прибылью при наличии всех доказательств подтверждающих полное исключение образования мусора необходимый расчёт заново делать не желает[12]. Все подмосковные собственники, входящие в Ногинскую зону (Балашиха, Реутов и т.д.) Московской области, обслуживаемую ООО «Хартия» по вопросам перерасчёта переадресовываются им опять посреднику - ООО «МосОблЕИРЦ» с которым ООО «Хартия» был заключен договор возмездного оказания по формированию единого платежного документа, содержащего строку «Обращение с TKO» и его доставку плательщикам-собственникам объектов недвижимости.

ООО «МосОблЕИРЦ», получив индульгенцию от ООО «Хартия» проявляет слишком явную заинтересованность на все свои дальнейшие дела по сбору, в том числе незаконного, денег с населения. Имитируя бурную деятельность, отсылает собственников, законно требующих перерасчёта, обратно к ООО «Хартия». При этом, чтобы получить деньги за воздух, прикрывает противоправную деятельность подмосковных регоператоров, озвучивает отмазки одна циничнее другой. Пытается запутать суть вопроса, например, утверждая, например, что, если проживание собственника по другому адресу (например, в Москве) постоянное, а не временное, то в таком случае основания для перерасчёта размера платы в порядке, предусмотренном разделом VIII Правил № 354 якобы не могут быть признаны обоснованными. Такого безнаказанного беспредела и издевательства над собственниками и здравым смыслом, нарушающим все законы логики, как в Московской области трудно найти в любом цивилизованном государстве мира (!). Любому вменяемому человеку понятно, что сам по себе

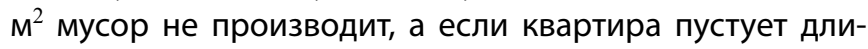

тельное время, то мусора там быть не может тем более. В судебной практике уже имеются несколько прецедентов, когда гражданам удалось добиться этого через суд (Балашихинский горсуд Московской области дело № 2-5705/2019, Королевский горсуд Московской области, дело № 2-3148/2019) справедливого решения. В данном случае договор публичной оферты обязательный для исполнения сторонами вне зависимости от воли и желания сторон или одной из стороны отношений становится просто фикцией так, как нет мусора предмета договора. Верховный суд РФ пока не давал по этому поводу комментариев, и говорить, что теперь это единая практика по всей стране, еще рано. Однако при наличии доказательств того, что жилье пустовало, дело может решиться в пользу истца. Пока же ООО «МосОблЕИРЦ» В коррупционном сговоре с ООО «Хартия», пользуясь полной бесконтрольностью и безнаказанностью со стороны прокурорских надзорных органов проявляет верх цинизма и берёт деньги за коммунальную услугу «Обращение с ТКО» даже с покойников, когда человек умер и в его квартире никто не прописан и не живёт, но расчёты всё равно производятся из расчёта площади (!) Чиновничий цинизм границ не знает. Апофеоз бюрократических игрищ, больше похож на очередное издевательство над народом. Как, собственно, и плата «за воздух», за «высосанный из пальца» мусор которого реально нет.

Не логична и ситуация, когда, например, с одинокого пенсионера-инвалида, имеющего в собственности четырёх- комнатную квартиру региональный оператор пытается вынудить не правомерно оплатить, исходя из размера жилплощади больше, чем с проживающих в том же многоквартирном доме малогабаритной однушки десяти мигрантов- гастарбайтеров.

Ещё более абсурдно положение, когда, например, собственник имеет несколько квартир в Московской области, но там не проживает и в аренду квартиры не сдаёт, поэтому мусор там естественно не образуется. Но с него местный регоператор ООО «Хартия», ссылаясь на договор оферты и отсутствие в Правилах механизма пересчёта платы за коммунальную услугу «Обращение с ТKO», из размера площади помещения пытается, используя неверное толкование закона « в свою пользу» получить деньги за ничего не делание.

Владельцам пустых участков за городом, на которых отсутствуют жилые постройки, также следует знать, что они не обязаны платить за вывоз ТKO, поскольку плата взимается только с владельцев жилых помещений. Начисление платы при пустом участке будет незаконным.

Чтобы оспорить начисление, следует предоставить оператору выписку из Росреестра, подтверждающую, 
что на конкретном участке жилые постройки отсутствуют. В случае, если решить проблему мирным путем не удалось, следует обратиться в районную прокуратуру.

Финансовые ресурсы, к которым смогут прибегнуть власти, заведомо недостаточны по сравнению с масштабом возникших проблем. На наш взгляд, для проведения масштабных мероприятий и реализации таких крупных проектов, как «мусорная реформа» вместо региональных операторов в виде приближенных к власти ООО с целью коренного улучшения финансирования модернизации отрасли по утилизации отходов следует в каждом субъекте РФ учредить Публичные акционерные общества (ПАО) [5].

В мире бизнеса так сложилось, что ПАО рассматриваются как более весомые и желанные деловые партнеры, с которыми безопаснее и выгоднее иметь дело. Такой организационно-правовой тип предприятия позволяет консолидировать инвестиции самых различных вкладчиков как крупных, так и мелких. По принципу «С мира по нитке - голому рубашка».

ПАО по реформированию мусорной реформы характеризуются тем, что акционерами являются прежде всего сами собственники жилья, которые будут более активно платить за коммунальную услугу «Обрашенние с TKO» целевым назначением непосредственно в ПАО, а не ООО регоператорам, чья репутация в деловом мире значительно уступает ПАО и их кредиту доверия.

Кроме того число участников ПАО неограниченно, их ценные бумаги находятся в открытом обращении их могут свободно приобрести третьи лица, причем их количество также не ограничено. Права отдельных участников заранее определены и не подлежат изменению. Предварительное согласие всех участников ПАО на продажу акций не требуется. Данные об акционерах закрыты для третьих лиц. Продажа акций ведётся с внесением данных в реестр акционеров. Реализация преимущественного права затруднена. Зафиксировать цену на акцию в Уставе невозможно. Отсутствуют ограничения на наследование акций. Обязательно учреждение ревизионной комиссии, что сводит к минимуму расходование средств на нецелевые расходы.

Для ПАО обязательны ежегодные проверки аудита и обнародование финансовых результатов деятельности общества.

У акционеров отсутствует личная материальная ответственность в случае убытков или банкротства фирмы. Риск связан только с принадлежащим им объемом акций ПАО.
ПАО имеет возможность значительно улучшить финансирование мусорной реформы привлекая больше инвестиций через дополнительную эмиссию ценных бумаг для их последующей продажи своим новым акционерам. ПАО могут привлекать значительные капиталовложения благодаря легкости приобретения акций, а также потому, что акционеру необязательно быть предпринимателем или участвовать в собраниях.

Многие владельцы жилья расценивают покупку акций в счёт оплаты коммунальной услуги «Обращение с ТКО» как одну из форм вложения капитала. Для ПАО стартовая сумма регистрации фиксируется на ста тыс. руб.

Синергия позволит ПАО существенно нарастить свои мощности и денежный поток. В отличие от ООО региональных операторов средства от коммунальной услуги «Обращение с ТКО» не будут оседать в карманах посредников, а будут направлены ПАО исключительно на создание современной мусорной отрасли с привлечением профессионалов, а не нынешних современных «гигантов мысли, отцов русской демократии и особ к приближённых к Императору» типа Кисы Воробьянинова из романа И. Ильфа и Е. Петрова «Двенадцать стульев». Надо сделать так, чтобы от авторитетного мнения эколога-профессионала у любого прохвоста, даже с липовыми высокими учёными степенями званиями и незаслуженными наградами «земля горела под ногами». Бороться с валом гнусных фальсификаций и сознательного возвеличивания провальной «мусорной реформы» можно только правдой и честной и открытой работой.

Но объективно в рамках государственно-олигархической капиталистической парадигмы, все создатели и реализаторы «мусорной реформы», в той или иной степени, являются рабами денежного капитала и вынуждены действовать в его интересах, даже тогда, когда (если) это ведет к катастрофе для них самих и всего человечества в целом (хотя неизбежность страшной экологической катастрофы осознается ими самими).

Выводы: Авторитет «мусорной реформы» в нынешнем виде иссяк и ресурс ее поддержки со стороны граждан прекратился. Она стала символом всего из наиболее ужасного, что было рядом с российской верховной властью. Реализация «мусорных преобразований» зашла в тупик и находится на последнем издыхании. Наиболее зримо характер мусорных изменений, как «финансового пузыря» и фантастического блефа, когда, казалось бы, самые элементарные вопросы можно решать только на спецсовещаниях президента с капитанами бизнеса проявился в финансовых вопросах при анализе факторов препятствующих финансово-правовому созданию 
прогрессивной современной мусорной отрасли. Часто делаемое создателями реформы не совпадает с задачами, поставленными перед ними, с законом, даже со здравым смыслом. Это происходит потому, что они знают, поскольку наказаны не будут, а любое проявленное населением недовольство или, сопротивление их «творческим» началам будет проигнорировано. Чтобы менять ситуацию надо полностью осознать реальность. Необходима принципиальная замена формы регистрации бизнеса с коррупционной системы региональных операторов в виде ООО на публичные акционерные общества собственников жилья по обращению с ТКО (ПАО), устра- нение факторов препятствующих нормальному функционированию финансово-правового законодательства. Иначе победа над мусором может оказаться Пирровой и повлечет за собой непредсказуемые для страны сокрушительные последствия. Россия устала от хода «мусорной реформы», которая стремительно обнажила истинное лицо и уровень государственного мышления её исполнителей. Экологическое будущее стало непрогнозируемым. «Мусорный кризис» еще не раскрылся окончательно. Не все ещё осознали новую действительность в нашей экологии. Но эта явно не радужная действительность, к сожалению, неизбежна.

\section{ЛИТЕРАТУРА}

1. Конституция (Основной Закон) Российской Федерации [принята всенародным голосованием 12.12.1993]: (с учетом поправок, внесенных Законами РФ о поправках к Конституции РФ от 30.12.2008 № 6-ФК3, от 30.12.2008 № 7-ФК3, 0т 05.02.2014 № 2-ФК3, от 21.07.2014 № 11-ФК3) // (3 РФ.— 2014.— № 31.-Ст. 4398

2. Гражданский кодекс РФ: Часть первая — четвертая: [принят Государственной Думой 21 октября 1994 г.] // Актуальная редакция ГК РФ от 16.12 .2019 г. (с изменениями, вступившими в силу с 01.01.2020 г.)

3. 0 защите прав потребителей: Федеральный закон от 09.01.1996 № 2300-01-Ф3: (с изменениями: от 17.12.1999 № 212-Ф3, 0т 30.12.2001 № 196-Ф3, от 22.08.2004 № 122-Ф3, от 02.11.2004 № 127-Ф3, от 21.12.2004 № 171-Ф3, от 27.07.2006 № 140-Ф3, от 16.10.2006 № 160-Ф3, 0т 25.11.2006 № 193-Ф3, от 25.10.2007 № 234-Ф3, от 23.07.2008 № 160-Ф3, от 03.06.2009 № 121-Ф3, от 23.11.2009 № 261-Ф3, от 27.06.2011 № 162-Ф3, 0т 18.07.2011 № 242-Ф3, от 25.06.2012 № 93-Ф3, от 28.07.2012 № 133-Ф3, от 02.07.2013 № 185-Ф3, от 21.12.2013 №363-Ф3, от 05.05.2014 № 112-Ф3, 0т 13.07.2015 № 233-Ф3, от 03.07.2016 № 265-Ф3, от 01.05.2017 № 88-Ф3, от 18.04.2018 № 81-Ф3, от 04.06.2018 № 133-Ф3, от 29.07.2018 № 250-Ф3, от 18.03.2019 № 38-Ф3, от 18.07.2019 № 191-Ф3) // publication.pravo.gov.ru Официальный интернет-портал правовой информации. Государственная система правовой информации.

4. Жилищный кодекс Российской Федерации: Федеральный закон № 188-Ф3: [принят Государственной Думой 22 декабря 2004 г.: одобрен Советом Федерации 24 декабря 2004 г.]: (ред. от 6 февраля 2020 г.) // publication.pravo.gov.ru 0фициальный интернет-портал правовой информации. Государственная система правовой информации.

5. 06 акционерных обществах: Федеральный закон от 26.12.1995 N208-Ф3 с изменениями, внесенными Федеральным законом 0т 04.11.2019 N356-Ф3 (ред. 65). Принят Государственной Думой 24 ноября 1995 года. publication.pravo.gov.ru 0фициальный интернет-портал правовой информации. Государственная система правовой информации.

6. 0 внесении изменений в Федеральный закон «0б отходах производства и потребления»: Федеральный закон от 29.12.2014 г. № 458 -Ф3 [принят Государственной Думой 23 декабря 2014 г.: одобрен Советом Федерации 25 декабря 2014 г.] // publication.pravo.gov.ru 0фициальный интернет-портал правовой информации. Государственная система правовой информации.

7. 0 внесении изменений в Федеральный закон «06 отходах производства и потребления»: Федеральный закон от 31.12 .2017 г. № 503-Ф3 [принят Государственной Думой 22 декабря 2017 г.: одобрен Советом Федерации 26 декабря 2017 г.]: (последняя редакция) // publication.pravo.gov.ru 0фициальный интернет-портал правовой информации. Государственная система правовой информации.

8. 0 национальных целях и стратегических задачах развития Российской Федерации на период до 2024 года. Указ Президента Российской Федерации от 07.05.2018 № 204. // Российская газета — Федеральный выпуск № 75601 (97), 9 мая 2018 г.

9. Об упорядочении деятельности совещательных и консультативных органов при Президенте Российской Федерации. Указ Президента Российской Федерации от 19.07. 2018 г. № 444. // www.kremlin.ru

10. Указ Президента Российской Федерации от 14 января 2020 г. № 8 «0 создании публично-правовой компании по формированию комплексной системы обращения с твёрдыми коммунальными отходами «Российский экологический оператор».// publication.pravo.gov.ru 0фициальный интернет-портал правовой информации. Государственная система правовой информации.

11. Указ Президента Российской Федерации от 15 января 2020 г. № 14 «0 Правительстве Российской Федерации».//publication.pravo.gov.ru 0фициальный интернет-портал правовой информации. Государственная система правовой информации.

12. 06 обращении с твердыми коммунальными отходами и внесении изменения в постановление Правительства Российской Федерации от 25 августа 2008 г. № 641: постановление Правительства РФ от 12.11.2016 № 1156 (ред. от 15.12.2018 г.) // publication.pravo.gov.ru. Официальный интернет-портал правовой информации. Государственная система правовой информации.

13. 0 предоставлении коммунальных услуг собственникам и пользователям помещений в многоквартирных домах и жилых домов: постановление Правительства РФ от 6 мая 2011 г. № 354 (с изменениями и дополнениями на 20.12.2018 г.) // publication.pravo.gov.ru 0фициальный интернет-портал правовой информации. Государственная система правовой информации. 
14. Правила осуществления деятельности по управлению многоквартирными домами: постановление Правительства РФ от 15 мая 2013 г. № 416 (ред. 13.09.2018 г.) // publication.pravo.gov.ru 0фициальный интернет-портал правовой информации. Государственная система правовой информации.

15. Паспорт национального проекта «Экология». Утверждён президиумом Совета при Президенте Российской Федерации по стратегическому развитию и национальным проектам (протокол от 24 декабря 2018 года № 16) // publication.pravo.gov.ru 0фициальный интернет-портал правовой информации. Государственная система правовой информации.

16. Российский статистический ежегодник. 2019.- - М., 2019.

17. Бедный Демьян. Собрание сочинений в 8 т. М. Издательство «Художественная литература», 1963-1965.

18. Голиченков А. К. «экологическое право России: словарь юридических терминов». М., Городец, 2012 г.,512 стр.

19. Зиновьев Н. А. «Избранное. М., Российский писатель, 2010 г., 144 стр.

20. Ильин А. Ю., Яговкина В. А., Кобзарь-Фролова М.Н., Ленева И. Г. «Финансовое право», учебник. Под ред. И. И. Кучерова. М. Издательство «Эксм0», 2011.590 стр.

21. Лобко А. А. «Говорить по-русски. Как интегрировать выходцев из бывшего Союза в российское общество» // «Литературная газета» № 1-2 (6627), 17 января 2018 г.

22. Лобко А. А. «Некоторые проблемы реализации конституционного права граждан на социальное обеспечение.» // Современная наука: актуальные проблемы теории и практики. Серия «Экономика и право», № 6, 2019 г., стр. 131-137

23. Лобко А. А. «Правовое регулирование социально-экономических проблем «мусорной реформы.» // Современная наука: актуальные проблемы теории и практики. Серия «Экономика и право», № 4, 2020 г., стр.181-201

24. Лобко А. Г. «Разноликие пластмассы. Кандидат экономических наук А. Г. Лобко рассказывает о том, как и кто изготавливает пластмассы и изделия из них.» М.: Знание, 1985. - 47 стр.: ил.; - (серия: Твоя профессия № 1).

25. Марченко М. Н. «Теория государства и права», учебник. 2-е изд., перераб. и доп. М.: Проспект, 2015.

26. Поветкина Н. А., Кучеров И. И., Акопян О. А. «Правовые средства обеспечения финансовой безопасности». М. Издательство Норма, 2019 г., 240 стр.

27. Райзберг Б. А., Лобко А. Г. «Программно-целевое планирование и управление», учебник. М., издательство «ИНФРА-М». Серия «Высшее образование», 2002 г., 428 стр.

28. Салтыков-Щедрин М. Е. Собрание сочинений в двадцати томах. М. Издательство «Художественная литература», 1965-1977.

(с) Лобко Анастасия Александровна ( naty.rubik@mail.ru ).

Журнал «Современная наука: актуальные проблемы теории и практики»

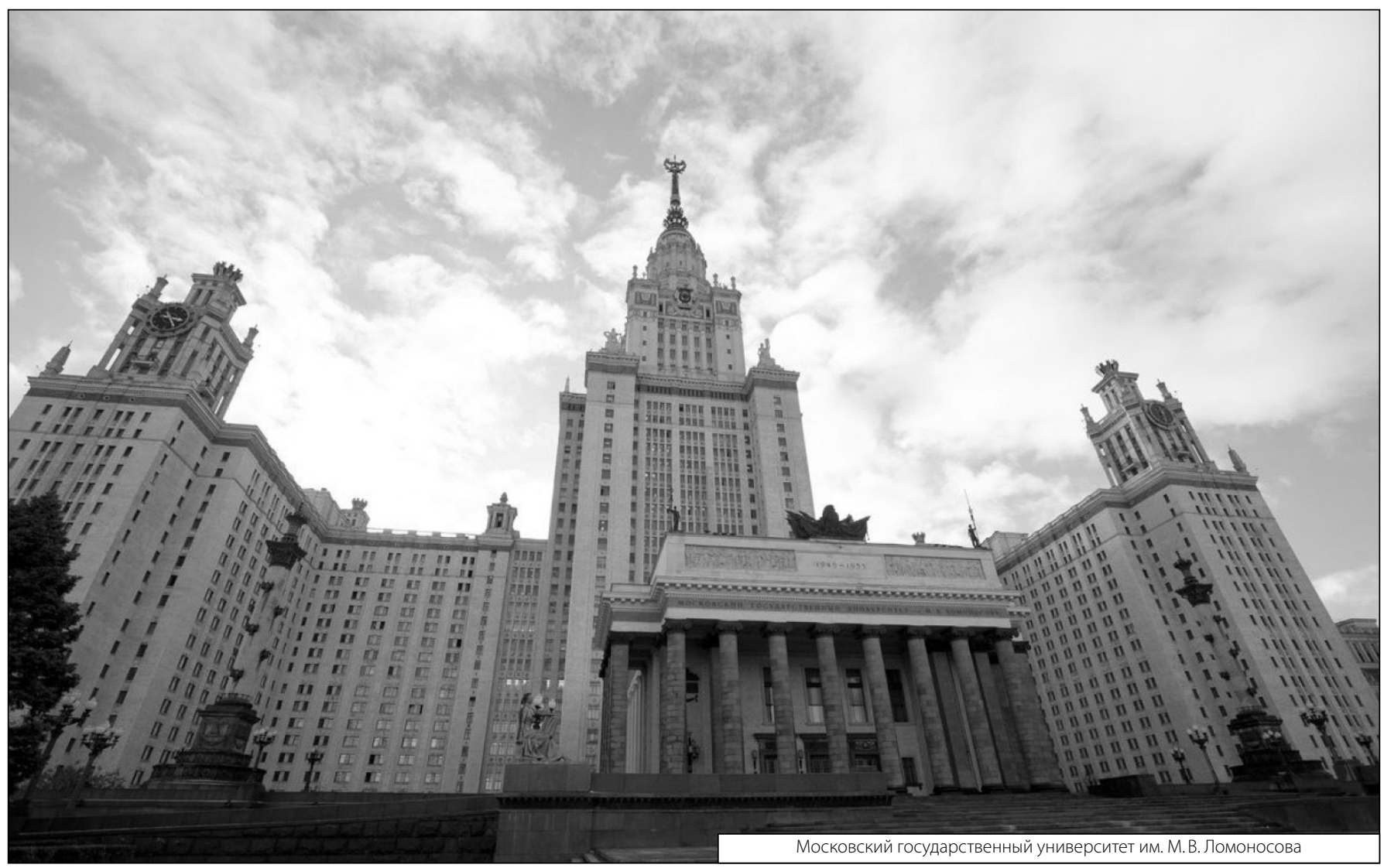

